STRUCTURE REPORTS

ISSN 1600-5368

Received 26 June 2014

Accepted 1 July 2014

Edited by M. Weil, Vienna University of Technology, Austria

Keywords: tin; oxalate; crystal structure

CCDC reference: 1011391

Supporting information: this article has supporting information at journals.iucr.org/e

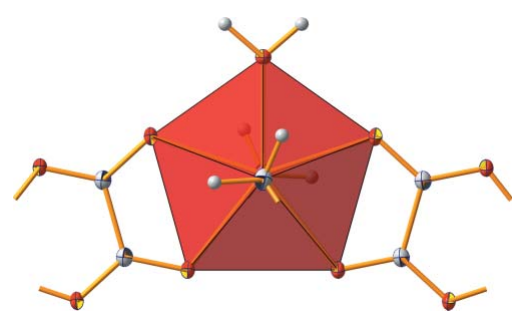

OPEN $\odot$ ACCESS

\section{Crystal structure of catena-poly[[aquadi-n-propyl- tin(IV)]- $\mu$-oxalato]}

\author{
Martin Reichelt and Hans Reuter*
}

Institut für Chemie neuer Materialien, Universität Osnabrück, Barbarastrasse 7, D-49069 Osnabrück, Germany. *Correspondence e-mail: hreuter@uos.de

The title compound, $\left[\mathrm{Sn}\left(\mathrm{C}_{3} \mathrm{H}_{7}\right)_{2}\left(\mathrm{H}_{2} \mathrm{O}\right)\left(\mathrm{C}_{2} \mathrm{O}_{4}\right)\right]_{n}$, represents the first diorganotin(IV) oxalate hydrate to be structurally characterized. The tin(IV) atom of the one-dimensional coordination polymer is located on a twofold rotation axis and is coordinated by two chelating oxalate ligands with two slightly different $\mathrm{Sn}-\mathrm{O}$ bond lengths of $2.290(2)$ and $2.365(2) \AA$, two symmetry-related $n$-propyl groups with a $\mathrm{Sn}-\mathrm{C}$ bond lengths of 2.127 (3) $\AA$, and a water molecule with a $\mathrm{Sn}-\mathrm{O}$ bond length of $2.262(2) \AA$. The coordination polyhedron around the $\mathrm{Sn}^{\mathrm{IV}}$ atom is a slightly distorted pentagonal bipyramid with a nearly linear axis between the trans-oriented $n$-propyl groups $\left[\mathrm{C}-\mathrm{Sn}-\mathrm{C}=176.8(1)^{\circ}\right]$. The bond angles between the oxygen atoms of the equatorial plane range from $70.48(6)^{\circ}$ to $76.12(8)^{\circ}$. A one-dimensional coordination polymer results from the less asymmetric bilateral coordination of the centrosymmetric oxalate anion, internally reflected by two slightly different $\mathrm{C}-\mathrm{O}$ bond lengths of 1.248 (3) and 1.254 (3) $\AA$. The chains of the polymer propagate parallel to [001] and are held together by hydrogen bonds between water molecules and oxalate anions of neighboring chains, leading to a two-dimensional network parallel to (100).

\section{Chemical context}

In a previous paper (Reichelt \& Reuter, 2014), we described the formation and structure of the first diorganotin(IV) oxalate $(O x),\left(R_{2} \operatorname{Sn}\right) O x$ for $R=t$-butyl in the course of a systematical study on the reaction of diorganotin(IV) oxides with nitric acid (Reuter \& Reichelt, 2014a,b). Applying similar reaction conditions to di- $n$-propyltin oxide resulted in the formation of the title compound as an unexpected side product. This diorganotin(IV) oxalate hydrate gives new insights into the structural chemistry of organotin(IV) oxalates.

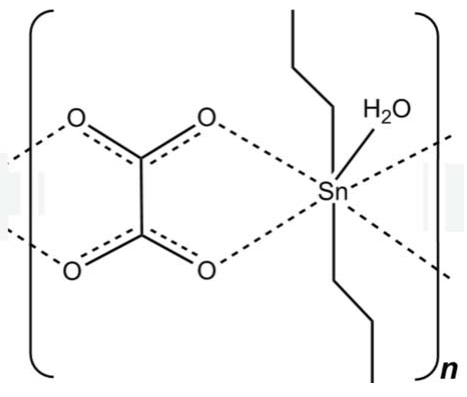

\section{Database survey}

Up to now, organotin(IV) oxalates were limited to a few representatives with general formula $\left(R_{3} \mathrm{Sn}\right)_{2} O x$, viz. $R=$ phenyl (Diop et al., 2003); $R=$ cyclohexyl (Ng et al., 1994) and a Lewis-base-stabilized one with general formula $\left[R_{3} \mathrm{Sn}(L B)\right]_{2} O x$, viz. $R=$ methyl, $L B=\mathrm{H}_{2} \mathrm{O}$ (Diop et al., 1997). 


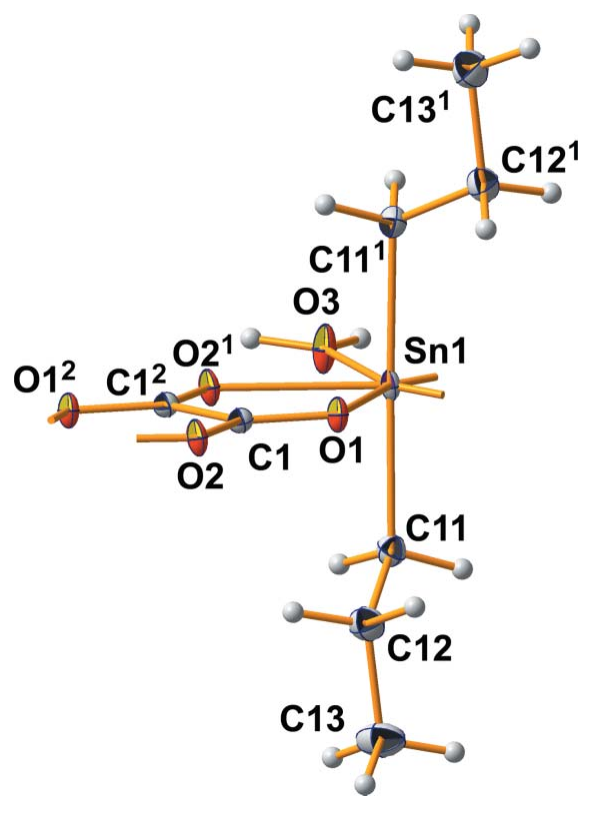

Figure 1

Ball-and-stick model of one formula unit in the crystal structure of the title compound with the atomic numbering scheme used. With exception of the $\mathrm{H}$ atoms, which are shown as spheres of arbitrary radius, all other atoms are drawn as displacement ellipsoids at the $50 \%$ probability level. [Symmetry codes: (1) $1-x, y, \frac{1}{2}-z$; (2) $1-x,-y, 1-z$.]

\section{Structural commentary}

The asymmetric unit of the title compound comprises one half of the formula unit (Fig. 1), consisting of an $\mathrm{Sn}^{\mathrm{IV}}$ atom lying on a twofold rotation axis, a water molecule with the $\mathrm{O}$ atom on the same rotation axis as the $\mathrm{Sn}$ atom, a bilateral chelating centrosymmetric oxalate anion and an $n$-propyl group attached to the Sn atom in general positions. Different from the unsubstituted $t$-butyl oxalate (Reichelt \& Reuter, 2014), the $\mathrm{Sn}^{\mathrm{IV}}$ atom is sevenfold coordinated by two $n$-propyl groups, four oxygen atoms of two symmetry-related oxalate anions and one water molecule.

As a result of of symmetry, both $\mathrm{Sn}-\mathrm{C}$ bond lengths are of equal length. At 2.127 (3) $\AA$, they are considerably shorter than the $\mathrm{Sn}-\mathrm{C}$ bond lengths of 2.186 (2) and 2.190 (2) $\AA$ in the di-t-butyl tin oxalate although the higher coordination number of the Sn atom in the hydrate compared with the Sn atom in the pure oxalate should result in longer bonds. This reflects the influence of the organic part ( $n$-propyl versus $t$-butyl) on $\mathrm{Sn}-\mathrm{C}$ bond length, as already mentioned by Britton (2006). The $n$-propyl group itself is well ordered as can be deduced from the aniostropic displacement parameters as well as from the $\mathrm{C}-\mathrm{C}$ bond lengths of 1.521 (3) and 1.522 (4) $\AA$, which are in good agreement with the values reported by Allen et al. (1987) for $s p^{3}$-hybridized carbon atoms $\left[1.513\right.$ (14) for $-\mathrm{CH}_{2}-\mathrm{CH}_{3}, 1.524$ (14) $\AA$ for $-\mathrm{CH}_{2}-$ $\left.\mathrm{CH}_{2}-\right]$. The corresponding bond angles are 117.0 (2) at $\mathrm{C} 11$ and $112.1(2)^{\circ}$ at $\mathrm{C} 12$. All in all, this group adopts a nearly staggered conformation with an $\mathrm{Sn} 1-\mathrm{C} 11-\mathrm{C} 12-\mathrm{C} 13$ torsion angle of $-174.3(2)^{\circ}$. Although both $n$-propyl groups attached to the $\mathrm{Sn}$ atom are related to each other by the twofold

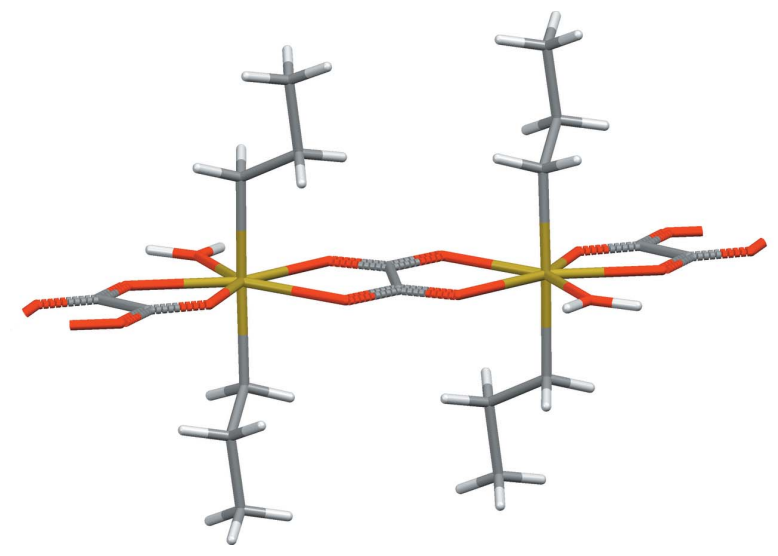

Figure 2

Stick-model showing a part of the one-dimensional coordination polymer. Colour code: $\mathrm{Sn}=$ bronze, $\mathrm{O}=$ red, $\mathrm{C}=$ dark grey, $\mathrm{H}=$ light grey.

rotation axis, the bond angle is not exactly $180^{\circ}$ because the $\mathrm{Sn}-\mathrm{C}$ bond is not exactly perpendicular to this axis.

The two symmetry-related oxalate anions coordinate sideon to the $\mathrm{Sn}$ atom with only slightly different $\mathrm{Sn}-\mathrm{O}$ bond lengths $[\mathrm{Sn} 1-\mathrm{O} 2=2.290$ (2) $\AA$ and $\mathrm{Sn} 1-\mathrm{O} 1=2.365$ (2) $\mathrm{A}]$. This symmetrical coordination mode is in sharp contrast to the asymmetrical coordination mode of the oxalate anions in the anhydrous $t$-butyl compound [2.150 (1) to 2.4245 (1) $\AA$ ] and is also reflected in $\mathrm{C}-\mathrm{O}$ bond lengths which are much more closer to each other $[\mathrm{C}-\mathrm{O}=1.248(3) / 1.254$ (3) $\AA, \Delta=$ $0.006 \AA]$ than in the $t$-butyl compound [1.242 (1)/1.269 (1) $\AA$, $\Delta=0.027 \AA]$ as an expression of more delocalized $\mathrm{C}=\mathrm{O}$ bonds. The oxalate ion itself is planar as it belongs to point group $C_{\mathrm{i}}$ and exhibits a $\mathrm{C}-\mathrm{C}$ bond length of 1.549 (4) $\AA$, [1.545 (3) $\AA]$, which is slightly longer than a normal bond between two $s p^{2}$-hybridized C atoms. From the bilateral, sideon coordination mode of the oxalate anion to the organotin moieties, a one-dimensional coordination polymer parallel to [001] results (Fig. 2).

It is remarkable that the sevenfold coordination of the Sn atom corresponds to a pentagonal bipyramid (Fig. 3). The axis formed by the two $n$-propyl groups is only slightly bent $\left[176.8(1)^{\circ}\right]$ at the $\mathrm{Sn}$ atom. Only one $\left[\mathrm{O} 1-\mathrm{Sn} 1-\mathrm{O} 1^{\mathrm{i}}=\right.$ $\left.76.12(8)^{\circ}\right]$ of the five $\left[\mathrm{O} 3-\mathrm{Sn} 1-\mathrm{O} 2^{\mathrm{ii}} / \mathrm{O} 2^{\mathrm{iii}}=71.60(4)^{\circ}\right.$; O $1 /$ $\mathrm{O} 1^{\mathrm{i}}-\mathrm{Sn} 1-\mathrm{O} 2^{\mathrm{iii}}=70.48(6)^{\circ}$; for symmetry codes see the Supporting information] bond angles between the $\mathrm{O}$ atoms of the equatorial plane deviates significantly from the ideal value

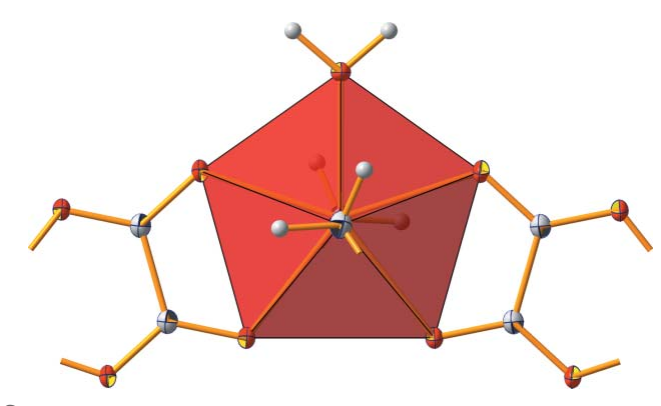

Figure 3

Schematic representation of the pentagonal-bipyramidal coordination polyhedron around the $\mathrm{Sn}$ atom. 
Table 1

Hydrogen-bond geometry $\left(\AA,^{\circ}\right)$.

\begin{tabular}{lllll}
\hline$D-\mathrm{H} \cdots A$ & $D-\mathrm{H}$ & $\mathrm{H} \cdots A$ & $D \cdots A$ & $D-\mathrm{H} \cdots A$ \\
\hline $\mathrm{O} 3-\mathrm{H} 3 \cdots \mathrm{O} 1^{\mathrm{i}}$ & 0.96 & 1.87 & $2.741(3)$ & 149 \\
\hline
\end{tabular}

Symmetry code: (i) $x, y+1, z$.

of $72^{\circ}$. These structural features are caused (i) by the distance of the chelating oxalate anion to the Sn atom, (ii) by the symmetrical position of the water molecule exactly between the two oxalate anions, and (iii) by a tilt of the plane of the oxalate anions relative to the least-squares plane through the atoms of the equatorial plane.

\section{Supramolecular features}

In the solid state, this coordination polymer is stabilized by hydrogen bonds (Table 1) between the water molecule of one chain as donor and the oxygen atom of the oxalate ion of neighboring chains as acceptor, and vice versa. As the plane of the water molecule coincides with the propagation plane of the coordination polymer, an almost planar, two-dimensional linkage of the chains results (Fig. 4). These planes are staggered one above the other with the $n$-propyl groups of one plane protruding into the shell of $n$-propyl groups of the neighboring plane (Fig. 5).

\section{Synthesis and crystallization}

Single crystals of the title compound were obtained as side products during the reaction of di- $n$-propyltin(IV) oxide with a large excess of concentrated nitric acid in ethanol. In a typical experiment, a mixture of $0.32 \mathrm{~g}(1.45 \mathrm{mmol}){ }^{n} \mathrm{Pr}_{2} \mathrm{SnO}$ and $1.5 \mathrm{ml}(21 \mathrm{mmol}) \mathrm{HNO}_{3}$ (Merck, 65\% $\left.\%_{\mathrm{wt}}\right)$ in $5 \mathrm{ml}$ ethanol was stirred at room temperature for several hours until a clear

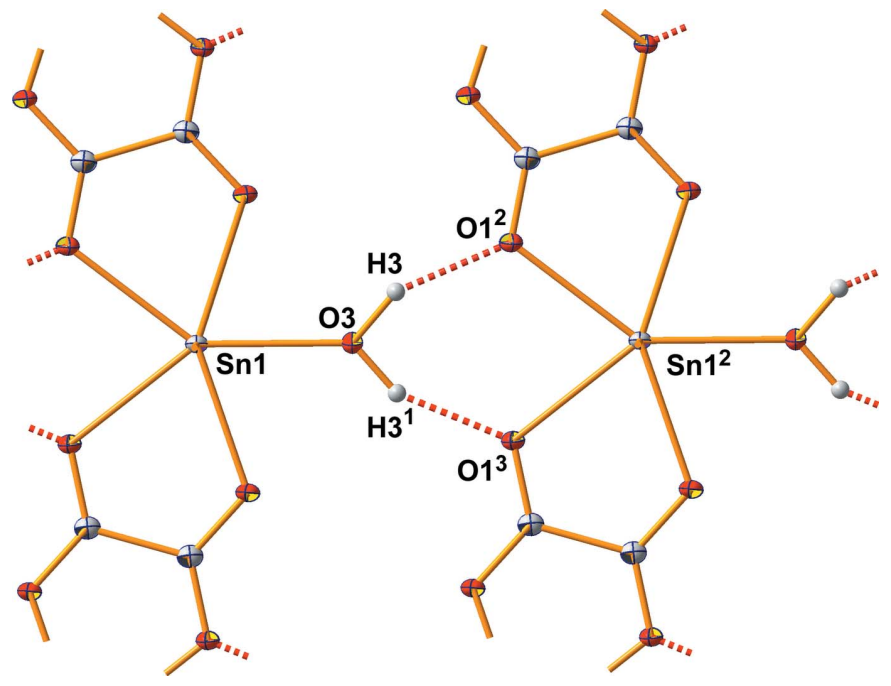

Figure 4

Part of the hydrogen-bonding (red dashed lines) system between adjacent chains of the one-dimensional coordination polymer. [Symmetry codes: (1) $1-x, y, \frac{1}{2}-z$; (2) $x, 1+y, z$; (3) $1-x, 1+y, \frac{1}{2}-z$.]
Table 2

Experimental details.

\begin{tabular}{|c|c|}
\hline \multicolumn{2}{|l|}{ Crystal data } \\
\hline Chemical formula & {$\left[\mathrm{Sn}\left(\mathrm{C}_{3} \mathrm{H}_{7}\right)_{2}\left(\mathrm{C}_{2} \mathrm{O}_{4}\right)\left(\mathrm{H}_{2} \mathrm{O}\right)\right]$} \\
\hline$M_{\mathrm{r}}$ & 310.90 \\
\hline Crystal system, space group & Monoclinic, $C 2 / c$ \\
\hline Temperature $(\mathrm{K})$ & 100 \\
\hline$a, b, c(\AA)$ & $16.6490(8), 6.4457(3), 11.5438(6)$ \\
\hline$\beta\left({ }^{\circ}\right)$ & $116.772(2)$ \\
\hline$V\left(\mathrm{~A}^{6}\right)$ & $1106.02(9)$ \\
\hline$Z$ & 4 \\
\hline Radiation type & Мo $K \alpha$ \\
\hline$\mu\left(\mathrm{mm}^{-1}\right)$ & 2.31 \\
\hline Crystal size $(\mathrm{mm})$ & $0.20 \times 0.15 \times 0.10$ \\
\hline \multicolumn{2}{|l|}{ Data collection } \\
\hline Diffractometer & Bruker APEXII CCD \\
\hline Absorption correction & $\begin{array}{l}\text { Multi-scan (SADABS; Bruker, } \\
\text { 2009) }\end{array}$ \\
\hline$T_{\min }, T_{\max }$ & $0.657,0.811$ \\
\hline $\begin{array}{l}\text { No. of measured, independent and } \\
\text { observed }[I>2 \sigma(I)] \text { reflections }\end{array}$ & $19736,1327,1255$ \\
\hline$R_{\mathrm{int}}$ & 0.062 \\
\hline$(\sin \theta / \lambda)_{\max }\left(\AA^{-1}\right)$ & 0.660 \\
\hline \multicolumn{2}{|l|}{ Refinement } \\
\hline$R\left[F^{2}>2 \sigma\left(F^{2}\right)\right], w R\left(F^{2}\right), S$ & $0.024,0.058,1.11$ \\
\hline No. of reflections & 1327 \\
\hline No. of parameters & 68 \\
\hline H-atom treatment & H-atom parameters constrained \\
\hline$\Delta \rho_{\max }, \Delta \rho_{\min }\left(\mathrm{e} \AA^{-3}\right)$ & $1.49,-0.91$ \\
\hline
\end{tabular}

Computer programs: APEX2 and SAINT (Bruker, 2009), SHELXS97, SHELXL97 and SHELXTL (Sheldrick, 2008), DIAMOND (Brandenburg, 2006) and Mercury (Macrae et al., 2008).

solution was obtained. Slow evaporation of solvents during some weeks resulted in the formation of colorless, blockshaped crystals of the title compound as well as crystals of an up-to-now unidentified reaction product. A suitable single crystal was selected under a polarization microscope and mounted on a $50 \mu \mathrm{m}$ MicroMesh MiTeGen Micromount ${ }^{\mathrm{TM}}$ using FROMBLIN Y perfluoropolyether (LVAC 16/6, Aldrich).

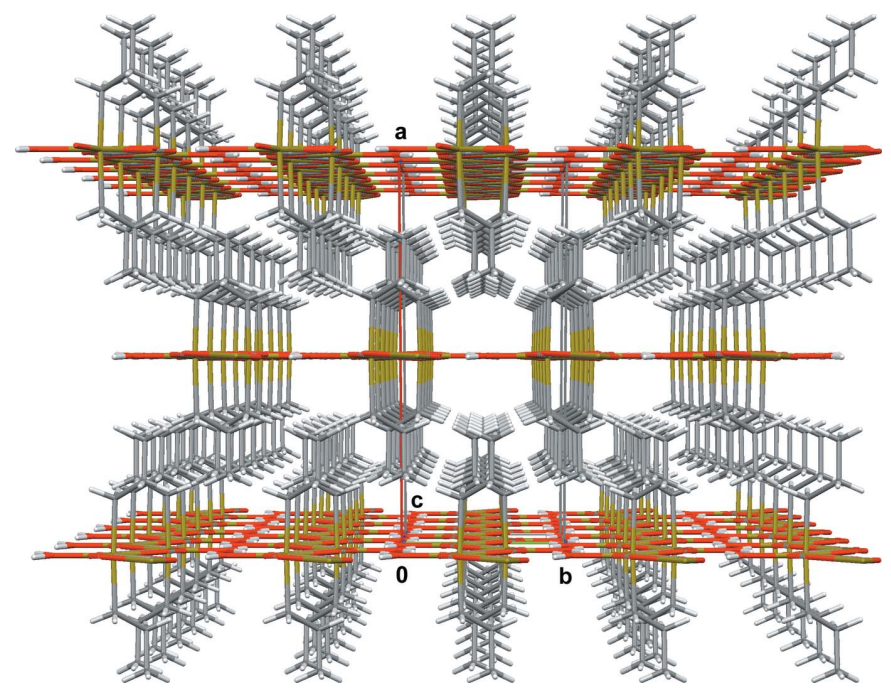

Figure 5

Perspective view of the crystal structure parallel to [001], looking down the chains of the one-dimensional coordination polymer. 


\section{Refinement}

All hydrogen atoms could be localized in difference Fourier syntheses. Those of the $n$-propyl group were idealized and refined at calculated positions riding on the carbon atoms with $\mathrm{C}-\mathrm{H}$ distances of $0.99 \AA\left(-\mathrm{CH}_{2}-\right)$ and $0.98 \AA\left(-\mathrm{CH}_{3}\right)$. Those of the water molecule were refined with respect to a common $\mathrm{O}-\mathrm{H}$ distance of $0.96 \AA$ and an $\mathrm{H}-\mathrm{O}-\mathrm{H}$ bond angle of $104.5^{\circ}$ before they were fixed and allowed to ride on the corresponding oxygen atom. For the hydrogen atoms of the $n$-propyl group, a common isotropic displacement parameter was refined as well as one common isotropic displacement parameter for the hydrogen atoms of the water molecule. Experimental details are summarized in Table 2.

\section{Acknowledgements}

We thank the Deutsche Forschungsgemeinschaft and the Government of Lower Saxony for funding the diffractometer.

\section{References}

Allen, F. H., Kennard, O., Watson, D. G., Brammer, L., Orpen, A. G. \& Taylor, R. (1987). J. Chem. Soc. Perkin Trans. 2, pp. S1-19.

Brandenburg, K. (2006). DIAMOND. Crystal Impact GbR, Bonn, Germany.

Britton, D. (2006). Acta Cryst. C62, m93-m94.

Bruker (2009). APEX2, SADABS and SAINT. Bruker AXS Inc., Madison, Wisconsin, USA.

Diop, L., Mahieu, B., Mahon, M. F., Molloy, K. C. \& Okio, K. Y. A. (2003). Appl. Organomet. Chem. 17, 881-882.

Diop, L., Mahon, M. F., Molloy, K. C. \& Sidibe, M. (1997). Main Group Met. Chem. 20, 649-654.

Macrae, C. F., Bruno, I. J., Chisholm, J. A., Edgington, P. R., McCabe, P., Pidcock, E., Rodriguez-Monge, L., Taylor, R., van de Streek, J. \& Wood, P. A. (2008). J. Appl. Cryst. 41, 466-470.

Ng, S. W., Kumar Das, V. G., Li, S.-L. \& Mak, T. C. W. (1994). J. Organomet. Chem. 467, 47-49.

Reichelt, M. \& Reuter, H. (2014). Acta Cryst. E70, m133.

Reuter, H. \& Reichelt, M. (2014a). Can. J. Chem. 92, 471-483.

Reuter, H. \& Reichelt, M. (2014b). Can. J. Chem. 92, 484-495.

Sheldrick, G. M. (2008). Acta Cryst. A64, 112-122. 


\section{supporting information}

Acta Cryst. (2014). E70, 87-90 [doi:10.1107/S1600536814015372]

\section{Crystal structure of catena-poly[[aquadi-n-propyltin(IV)]- $\mu$-oxalato]}

\section{Martin Reichelt and Hans Reuter}

\section{Computing details}

Data collection: SMART (Bruker, 2009); cell refinement: SAINT (Bruker, 2009); data reduction: SAINT (Bruker, 2009); program(s) used to solve structure: SHELXS97 (Sheldrick, 2008); program(s) used to refine structure: SHELXL97 (Sheldrick, 2008); molecular graphics: DIAMOND (Brandenburg, 2006) and Mercury (Macrae et al., 2008); software used to prepare material for publication: SHELXTL (Sheldrick, 2008).

catena-Poly[[aquadi-n-propyltin(IV)]- $\mu$-oxalato]

Crystal data

$\left[\mathrm{Sn}\left(\mathrm{C}_{3} \mathrm{H}_{7}\right)_{2}\left(\mathrm{C}_{2} \mathrm{O}_{4}\right)\left(\mathrm{H}_{2} \mathrm{O}\right)\right]$

$F(000)=616$

$M_{r}=310.90$

Monoclinic, $C 2 / c$

Hall symbol: $-\mathrm{C} 2 \mathrm{yc}$

$a=16.6490(8) \AA$

$b=6.4457(3) \AA$

$c=11.5438(6) \AA$

$\beta=116.772(2)^{\circ}$

$V=1106.02(9) \AA^{3}$

$Z=4$

$D_{\mathrm{x}}=1.867 \mathrm{Mg} \mathrm{m}^{-3}$

Mo $K \alpha$ radiation, $\lambda=0.71073 \AA$

Cell parameters from 9966 reflections

$\theta=2.7-28.7^{\circ}$

$\mu=2.31 \mathrm{~mm}^{-1}$

$T=100 \mathrm{~K}$

Plate, colourless

$0.20 \times 0.15 \times 0.10 \mathrm{~mm}$

\section{Data collection}

Bruker APEXII CCD

diffractometer

Radiation source: fine-focus sealed tube

Graphite monochromator

$\varphi$ and $\omega$ scans

Absorption correction: multi-scan

(SADABS; Bruker, 2009)

$T_{\min }=0.657, T_{\max }=0.811$

19736 measured reflections

1327 independent reflections

1255 reflections with $I>2 \sigma(I)$

$R_{\text {int }}=0.062$

$\theta_{\text {max }}=28.0^{\circ}, \theta_{\min }=2.7^{\circ}$

$h=-20 \rightarrow 21$

$k=-8 \rightarrow 8$

$l=-15 \rightarrow 13$

\section{Refinement}

Refinement on $F^{2}$

Least-squares matrix: full

$R\left[F^{2}>2 \sigma\left(F^{2}\right)\right]=0.024$

$w R\left(F^{2}\right)=0.058$

$S=1.11$

1327 reflections

68 parameters

0 restraints

Primary atom site location: structure-invariant direct methods

Secondary atom site location: difference Fourier map

Hydrogen site location: inferred from neighbouring sites

$\mathrm{H}$-atom parameters constrained

$w=1 /\left[\sigma^{2}\left(F_{0}^{2}\right)+(0.0357 P)^{2}+0.058 P\right]$

where $P=\left(F_{\mathrm{o}}{ }^{2}+2 F_{\mathrm{c}}{ }^{2}\right) / 3$

$(\Delta / \sigma)_{\max }<0.001$

$\Delta \rho_{\max }=1.49 \mathrm{e} \AA^{-3}$

$\Delta \rho_{\min }=-0.91$ e $\AA^{-3}$ 


\section{Special details}

Geometry. All e.s.d.'s (except the e.s.d. in the dihedral angle between two 1.s. planes) are estimated using the full covariance matrix. The cell e.s.d.'s are taken into account individually in the estimation of e.s.d.'s in distances, angles and torsion angles; correlations between e.s.d.'s in cell parameters are only used when they are defined by crystal symmetry. An approximate (isotropic) treatment of cell e.s.d.'s is used for estimating e.s.d.'s involving 1.s. planes.

Refinement. Refinement of $F^{2}$ against ALL reflections. The weighted $R$-factor $w R$ and goodness of fit $S$ are based on $F^{2}$, conventional $R$-factors $R$ are based on $F$, with $F$ set to zero for negative $F^{2}$. The threshold expression of $F^{2}>\sigma\left(F^{2}\right)$ is used only for calculating $R$-factors (gt) etc. and is not relevant to the choice of reflections for refinement. $R$-factors based on $F^{2}$ are statistically about twice as large as those based on $F$, and $R$ - factors based on ALL data will be even larger.

Fractional atomic coordinates and isotropic or equivalent isotropic displacement parameters $\left(\hat{A}^{2}\right)$

\begin{tabular}{lllll}
\hline & $x$ & $y$ & $z$ & $U_{\text {iso }} * / U_{\text {eq }}$ \\
\hline Sn1 & 0.5000 & $0.13504(3)$ & 0.2500 & $0.01108(10)$ \\
C11 & $0.35701(18)$ & $0.1258(3)$ & $0.1538(3)$ & $0.0165(5)$ \\
H111 & 0.3343 & 0.2589 & 0.1703 & $0.028(3)^{*}$ \\
H112 & 0.3376 & 0.1174 & 0.0593 & $0.028(3)^{*}$ \\
C12 & $0.31172(17)$ & $-0.0495(4)$ & $0.1905(3)$ & $0.0210(5)$ \\
H121 & 0.3245 & -0.0336 & 0.2825 & $0.028(3)^{*}$ \\
H122 & 0.3374 & -0.1836 & 0.1816 & $0.028(3)^{*}$ \\
C13 & $0.21034(18)$ & $-0.0522(5)$ & $0.1060(3)$ & $0.0304(7)$ \\
H131 & 0.1845 & 0.0790 & 0.1163 & $0.028(3)^{*}$ \\
H132 & 0.1839 & -0.1675 & 0.1325 & $0.028(3)^{*}$ \\
H133 & 0.1974 & -0.0698 & 0.0150 & $0.028(3)^{*}$ \\
O1 & $0.50631(12)$ & $-0.1538(2)$ & $0.38012(17)$ & $0.0131(4)$ \\
C1 & $0.50270(17)$ & $-0.1155(3)$ & $0.4836(2)$ & $0.0117(5)$ \\
O2 & $0.50337(11)$ & $-0.2472(3)$ & $0.56400(15)$ & $0.0141(4)$ \\
O3 & 0.5000 & $0.4860(4)$ & 0.2500 & $0.0203(6)$ \\
H3 & 0.5017 & 0.5767 & 0.3170 & $0.033(8)^{*}$ \\
\hline
\end{tabular}

Atomic displacement parameters $\left(\AA^{2}\right)$

\begin{tabular}{lllllll}
\hline & $U^{11}$ & $U^{22}$ & $U^{33}$ & $U^{12}$ & $U^{13}$ & $U^{23}$ \\
\hline Sn1 & $0.01603(15)$ & $0.01051(14)$ & $0.00986(14)$ & 0.000 & $0.00864(10)$ & 0.000 \\
C11 & $0.0170(12)$ & $0.0195(14)$ & $0.0133(12)$ & $0.0013(9)$ & $0.0071(10)$ & $0.0020(9)$ \\
C12 & $0.0209(13)$ & $0.0223(14)$ & $0.0207(13)$ & $-0.0020(11)$ & $0.0101(11)$ & $0.0024(11)$ \\
C13 & $0.0226(14)$ & $0.0369(17)$ & $0.0298(16)$ & $-0.0058(13)$ & $0.0101(12)$ & $0.0091(13)$ \\
O1 & $0.0198(9)$ & $0.0118(8)$ & $0.0100(9)$ & $0.0014(6)$ & $0.0088(7)$ & $0.0005(5)$ \\
C1 & $0.0104(11)$ & $0.0139(12)$ & $0.0106(11)$ & $0.0001(9)$ & $0.0046(9)$ & $-0.0002(9)$ \\
O2 & $0.0222(9)$ & $0.0126(9)$ & $0.0121(8)$ & $0.0015(7)$ & $0.0119(7)$ & $0.0013(6)$ \\
O3 & $0.0420(16)$ & $0.0096(12)$ & $0.0156(12)$ & 0.000 & $0.0185(12)$ & 0.000 \\
\hline
\end{tabular}

Geometric parameters $\left(A,{ }^{\circ}\right)$

\begin{tabular}{llll}
\hline $\mathrm{Sn} 1-\mathrm{C} 11$ & $2.127(3)$ & $\mathrm{C} 12-\mathrm{H} 121$ & 0.9900 \\
$\mathrm{Sn} 1-\mathrm{C} 11^{\mathrm{i}}$ & $2.127(3)$ & $\mathrm{C} 12-\mathrm{H} 122$ & 0.9900 \\
$\mathrm{Sn} 1-\mathrm{O} 3$ & $2.262(2)$ & $\mathrm{C} 13-\mathrm{H} 131$ & 0.9800 \\
$\mathrm{Sn} 1-\mathrm{O} 2^{\mathrm{ii}}$ & $2.290(2)$ & $\mathrm{C} 13-\mathrm{H} 132$ & 0.9800 \\
$\mathrm{Sn} 1-\mathrm{O} 2^{\mathrm{iii}}$ & $2.290(2)$ & $\mathrm{C} 13-\mathrm{H} 133$ & 0.9800
\end{tabular}




\begin{tabular}{|c|c|c|c|}
\hline $\mathrm{Sn} 1-\mathrm{O} 1$ & $2.365(2)$ & $\mathrm{O} 1-\mathrm{C} 1$ & $1.248(3)$ \\
\hline $\mathrm{Sn} 1-\mathrm{O} 1^{\mathrm{i}}$ & $2.365(2)$ & $\mathrm{C} 1-\mathrm{O} 2$ & $1.254(3)$ \\
\hline $\mathrm{C} 11-\mathrm{C} 12$ & $1.521(3)$ & $\mathrm{C} 1-\mathrm{C} 1^{\mathrm{ii}}$ & $1.549(4)$ \\
\hline $\mathrm{C} 11-\mathrm{H} 111$ & 0.9900 & $\mathrm{O} 2-\mathrm{Sn} 1^{\mathrm{ii}}$ & $2.290(2)$ \\
\hline $\mathrm{C} 11-\mathrm{H} 112$ & 0.9900 & $\mathrm{O} 3-\mathrm{H} 3$ & 0.9600 \\
\hline $\mathrm{C} 12-\mathrm{C} 13$ & $1.522(4)$ & & \\
\hline $\mathrm{C} 11-\mathrm{Sn} 1-\mathrm{C} 11^{\mathrm{i}}$ & $176.8(1)$ & $\mathrm{Sn} 1-\mathrm{C} 11-\mathrm{H} 111$ & 108.0 \\
\hline $\mathrm{C} 11-\mathrm{Sn} 1-\mathrm{O} 3$ & $91.60(6)$ & $\mathrm{C} 12-\mathrm{C} 11-\mathrm{H} 112$ & 108.0 \\
\hline $\mathrm{C} 11^{\mathrm{i}}-\mathrm{Sn} 1-\mathrm{O} 3$ & $91.60(6)$ & $\mathrm{Sn} 1-\mathrm{C} 11-\mathrm{H} 112$ & 108.0 \\
\hline $\mathrm{C} 11-\mathrm{Sn} 1-\mathrm{O} 2^{\mathrm{ii}}$ & $90.23(8)$ & $\mathrm{H} 111-\mathrm{C} 11-\mathrm{H} 112$ & 107.3 \\
\hline $\mathrm{C} 11^{\mathrm{i}}-\mathrm{Sn} 1-\mathrm{O} 2^{\mathrm{ii}}$ & $90.78(8)$ & $\mathrm{C} 11-\mathrm{C} 12-\mathrm{C} 13$ & $112.1(2)$ \\
\hline $\mathrm{O} 3-\mathrm{Sn} 1-\mathrm{O} 2^{\mathrm{ii}}$ & $71.60(4)$ & $\mathrm{C} 11-\mathrm{C} 12-\mathrm{H} 121$ & 109.2 \\
\hline $\mathrm{C} 11-\mathrm{Sn} 1-\mathrm{O} 2^{\mathrm{iii}}$ & $90.78(8)$ & $\mathrm{C} 13-\mathrm{C} 12-\mathrm{H} 121$ & 109.2 \\
\hline $\mathrm{C} 11^{\mathrm{i}}-\mathrm{Sn} 1-\mathrm{O} 2^{\mathrm{iii}}$ & $90.23(8)$ & $\mathrm{C} 11-\mathrm{C} 12-\mathrm{H} 122$ & 109.2 \\
\hline $\mathrm{O} 3-\mathrm{Sn} 1-\mathrm{O} 2^{\mathrm{iii}}$ & $71.60(4)$ & $\mathrm{C} 13-\mathrm{C} 12-\mathrm{H} 122$ & 109.2 \\
\hline $\mathrm{O} 2^{\mathrm{ii}}-\mathrm{Sn} 1-\mathrm{O} 2^{\mathrm{iii}}$ & $143.20(8)$ & $\mathrm{H} 121-\mathrm{C} 12-\mathrm{H} 122$ & 107.9 \\
\hline $\mathrm{C} 11-\mathrm{Sn} 1-\mathrm{O} 1$ & $91.65(8)$ & $\mathrm{C} 12-\mathrm{C} 13-\mathrm{H} 131$ & 109.5 \\
\hline 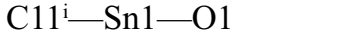 & $85.83(8)$ & $\mathrm{C} 12-\mathrm{C} 13-\mathrm{H} 132$ & 109.5 \\
\hline $\mathrm{O} 3-\mathrm{Sn} 1-\mathrm{O} 1$ & $141.94(4)$ & H131- C13-H132 & 109.5 \\
\hline $\mathrm{O} 22^{\mathrm{ii}}-\mathrm{Sn} 1-\mathrm{O} 1$ & $70.48(6)$ & $\mathrm{C} 12-\mathrm{C} 13-\mathrm{H} 133$ & 109.5 \\
\hline $\mathrm{O} 22^{\mathrm{iii}}-\mathrm{Sn} 1-\mathrm{O} 1$ & $146.23(6)$ & $\mathrm{H} 131-\mathrm{C} 13-\mathrm{H} 133$ & 109.5 \\
\hline $\mathrm{C} 11-\mathrm{Sn} 1-\mathrm{O} 1^{\mathrm{i}}$ & $85.83(8)$ & $\mathrm{H} 132-\mathrm{C} 13-\mathrm{H} 133$ & 109.5 \\
\hline $\mathrm{C} 11^{\mathrm{i}}-\mathrm{Sn} 1-\mathrm{O} 1^{\mathrm{i}}$ & $91.65(8)$ & $\mathrm{C} 1-\mathrm{O} 1-\mathrm{Sn} 1$ & $116.4(1)$ \\
\hline $\mathrm{O} 3-\mathrm{Sn} 1-\mathrm{O} 1^{\mathrm{i}}$ & $141.94(4)$ & $\mathrm{O} 1-\mathrm{C} 1-\mathrm{O} 2$ & $125.9(2)$ \\
\hline $\mathrm{O} 2^{\mathrm{ii}}-\mathrm{Sn} 1-\mathrm{O} 1^{\mathrm{i}}$ & $146.23(6)$ & $\mathrm{O} 1-\mathrm{C} 1-\mathrm{C} 1^{\mathrm{ii}}$ & $117.2(3)$ \\
\hline 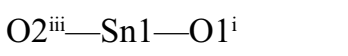 & $70.48(6)$ & $\mathrm{O} 2-\mathrm{C} 1-\mathrm{C} 1^{\mathrm{ii}}$ & $116.9(3)$ \\
\hline $\mathrm{O} 1-\mathrm{Sn} 1-\mathrm{O} 1^{\mathrm{i}}$ & $76.12(8)$ & $\mathrm{C} 1-\mathrm{O} 2-\mathrm{Sn} 1^{\mathrm{ii}}$ & $119.0(2)$ \\
\hline $\mathrm{C} 12-\mathrm{C} 11-\mathrm{Sn} 1$ & $117.0(2)$ & $\mathrm{Sn} 1-\mathrm{O} 3-\mathrm{H} 3$ & 127.5 \\
\hline $\mathrm{C} 12-\mathrm{C} 11-\mathrm{H} 111$ & 108.0 & & \\
\hline $\mathrm{Sn} 1-\mathrm{C} 11-\mathrm{C} 12-\mathrm{C} 13$ & $-174.3(2)$ & & \\
\hline
\end{tabular}

Symmetry codes: (i) $-x+1, y,-z+1 / 2$; (ii) $-x+1,-y,-z+1$; (iii) $x,-y, z-1 / 2$.

Hydrogen-bond geometry $\left(A,{ }^{\circ}\right)$

\begin{tabular}{lllll}
\hline$D-\mathrm{H} \cdots A$ & $D-\mathrm{H}$ & $\mathrm{H} \cdots A$ & $D \cdots A$ & $D-\mathrm{H} \cdots A$ \\
\hline $\mathrm{O} 3-\mathrm{H} 3 \cdots \mathrm{O} 1^{\text {iv }}$ & 0.96 & 1.87 & $2.741(3)$ & 149 \\
\hline
\end{tabular}

Symmetry code: (iv) $x, y+1, z$. 